\title{
DINAMIKA PESANTREN KONTEMPORER
}

\author{
Syamsul Ma'arif \\ IAIN Walisongo Semarang \\ Email: syamsulmaarif1974@yahoo.co.id
}

\section{Abstract}

This article will explain about the contemporary developments in the pesantren (Islamic boarding schools), especially its role in maintaining the tradition and stem infiltration of religious radicalism at the pesantren. The steps that can be used by pesantren is by teaching inclusive faith and the reformulation of multicultural curriculum for the students (santri). All this, with consideration for each movement by fundamentalists and extremists who cast a "jihad" to fight against those who disagree actually do not fit with the character and cultural of the pesantren. Is not the pesantren has always showed his attitude that it is always accommodating and understanding of diversity?

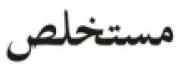

هذه المقالة سوف شرح عن التطورات المعاصرة في المعهد الاسلامية وخصو صا دورها في الحفاظ على التقاليد ورقف تسلل التطرف الديني في المعهد الاسلامية. الخطوات التئي يمكن استخدامها المعهد الاسلامية هي تدريس العقيدة شاملة وإعادة هياغة المناهج المتعددة الثقافات للطلاب (santri)، كل هذا ، مع النظر في كل -حركة هن قبل

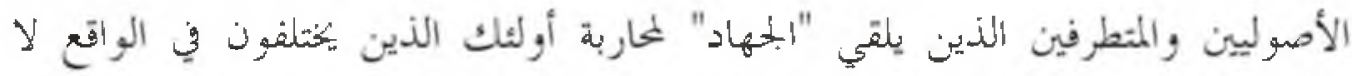
تتناسب مع طابع والثثافية في المعهد الاسلامية . ليست ما زالت المعهد الاسلاميه أظظهر ت موقفه وهو استيعاب وفهم التنوع دائما ؟

Keywords. Radikalisme, Pesantren dan Aqidah Inklusif 


\section{A. Pendahuluan}

Semua maklum pesantren merupakan bentuk pendidikan Islam tertua di Indonesia, dan tak diketahui kapan mulai awal berdirinya. Tapi menelisik sejumlah statement para pakar, sejarah awal berdirinya bersamaan dengan perkembangan Islam di Jawa sekitar abad 15 dan 16, bersamaan dengan sejarah dakwah yang dilakukan oleh para walisongo. ${ }^{1}$ Karakteristik yang sangat menonjol pembelajaran di pesantren lebih menekankan pada karakter moral dan indigenous budaya lokal Jawa. Karenannya wajah Islam yang ditrasmisikan para kiai di pesantren pada dasarnya adalah Islam inklusif dan menebarkan kedamaian di muka bumi (rahmatan lil'alamin). ${ }^{2} \mathrm{Hal}$ ini disebabkan para kiai pesantren biasanya meneruskan ajaran para walisongo yang selalu mengajarkan sopan santun, toleran dan menghormati budaya lokal.

Bahkan berdasarkan realitas sejarah, pada dasarnya pesantren dilahirkan untuk memberikan respon terhadap situasi dan kondisi sosial suatu masyarakat yang tengah dihadapkan pada runtuhnya sendi-sendi moral melalui transformasi nilai yang ditawarkanya (amar ma'ruf nahi munkar). Kehadiran pesantren bisa disebut sebagai agen perubahan sosial yang selalu melakukan kerja-kerja pembebasan pada masyarakat dari keburukan moral, penindasan dan kemiskinan. Selain itu, berdirinya pesantren juga memiliki misi untuk menyebarluaskan informasi ajaran universalitas Islam keseluruh pelosok Nusantara yang berwatak pluralis. ${ }^{3}$

Jadi sangat kontraproduktif manakala terjadi opini yang mengeklaim pesantren adalah sebagai sarang teroris dan menyebarkan kebencian terhadap non-muslimterutama pasca pengeboman di sejumlah tempat di Indonesia, baru-baru ini. Meskipun harus diakui, para teroris tersebut ditengarai oleh sejumlah pengamat sebagai seseorang yang memiliki hubungan dengan salah satu pesantren di Jawa

1 Berbicara tentang pesantren tidak bisa melupakan peran besar yang diberikan Walisongo. Walisongo adalah tokoh-tokoh penyebarIslam di Jawa abad 16 - 15 yang telah berhasil mengkombinasikan aspek-aspek sekuler dan spiritual dalam memperkenalkan Islam pada masyarakat. Lihat Abdurrahman Mas'ud, Dinamika Pesantren dan Madrasah, (Yogyakarta: Pustaka Pelajar, 2002), hal. 4.

2 Tentang persoalan ini taksalah jika Thomas Arnold dalam The Preaching of Islam mengatakan bahwa kedatangan Islam bukanlah sebagai penakluk seperti halnya bangsa Portugis dan Spanyol. Islam datang ke Asia Tenggara dengan jalan damai, tidak dengan pedang, tidak dengan merebut kekuasaan politik. Islam masuk ke Nusantara dengan cara yang benar-benar menunjukkannya sebagai rahmatan lil'alamin.

3 Saifudin Zuhri, "Pendidikan Pesantren di Persimpangan Jalan"dalam Marzuki Wahid,dkk. Pesantren Masa Depan Wacana Pemberdayaan dan Transformasi Pesantren, (Bandung: Pustaka Hidayah,1999), Hal 201. 
Tengah (Ngruki) atau bisa dikatakan sebagai jebolan dari pesantren sekunder yang memiliki keterkaitan dengan pesantren ini. Bahkan Amrozy Cs pelaku bom Bali pertama yang menggembarkan dunia internasional juga memberikan pengakuan bahwa dirinya beserta rekanya adalah alumni pesantren. ${ }^{4}$ Tapi tidaklah arif, jika secara terburu-buru mengeneralisasikan bahwa semua jebolan pesantren alias "santri" adalah teroris. Sebab, bentuk dan jenis pesantren di Indonesia sangat banyak, tergantung idiologi dan afiliasi organisasi yang dianaut para kiai dan santrinya.

Bukankan pesantren sendiri juga telah mengalami dinamika perkembangan yang sangat pesat? Bahkan menurut Badrus Shaleh, ${ }^{5}$ sekarang ini telah bermunculan sejumlah pesantren yang memiliki kecenderungan berbeda dengan jenis pesantren mainstream yang didirikan oleh para kiai penerus perjuangan para walisongo tersebut. Yaitu jenis "pesantren baru yang cenderung radikal, eksklusif dan non-akomodatif, bahkan lekat dengan gerakan kekerasan berlandaskan idiologi agama”, seperti harus menyerukan jihad ke daerah-daerah konflik antara muslim-kristen di Poso dan Maluku, pada waktu lalu.

Martin van Bruinessen dalam tulisan berjudul "Traditionalist and Islamist pesantren in contemporary Indonesia" juga telah menunjukkan kecenderungan bergesernya paradigma pesantren di beberapa daerah di Indonesia yang berbeda dengan pesantren mainstrem tersebut. Beberapa bentuk pesantren jenis ini, oleh Martin disebut sebagai pesantren yang memiliki jaringan dengan Jama'ah Islamiyah atau dengan gerakan Darul Islam diantaranya adalah; PP Al-Mukmin Ngruki dekat Solo, pesantren Hidayatullah di Balikpapan Kalimantan Timur, dan Pesantren AlZaytun di Indramayu. ${ }^{6}$ Semua pesantren ini ditengarai memiliki sumber-sumber keuangan yang "meragukan" dan sempat menimbulkan kecurigaan banyak pihak.

Kenyataan tersebut juga dipertegas dengan laporan Direktur International Crisis Group, Sydney Jones melalui artikel berjudul "Al-Qaidah in Southeast Asia: The Case of the "Al-Mukmin Network in Indonesia" yang menyatakan sesungguhnya terdapat jaringan reorisme di Indonesia yang dipimpin oleh Ustadz Abu Bakar Ba'asyir melalui pesantren Al-Mukmin Ngruki. ${ }^{7}$

4 Kompas,18 Nopember 2002.

5 Lihat Badrus Saleh dalam makalah berjudul "PESANTREN DAN PERDAMAIAN REGIONAL"dalam www.ditpertais.net/annualconference/ancon06/makalah/Makalah\%20 Badrus\%20Sholeh.doc.

6. Martin van Bruinessen, ISIM, Netherlands Paper presented at the ISIM workshop on 'The Madrasa in Asia', 23-24 May 2004. Dalam http://murtaufiq.blogspot.com/2008_09_01_archive.html. Murbu Abu, Memahami Terorisme di Indonesia, dalam A. Maftuh Abegebriel,(eds), NegaraTuhan:The Thematic Encyclopedia, (Jakarta: SR-Ins Publishing, 2004), hal. 750. 
Meskipun demikian, berdasarkan penelitian sesungguhnya sejumlah santri yang terlibat gerakan radikal tersebut sangat kuat dipengaruhi oleh pengalaman setelah selesai pendidikan di pesantren, baik di Malaysia, Afghanistan maupun tempat dan kegiatan lain. Mereka juga mendapat inspirasi dan kekuatan gerakan dari jaringan yang dibangun berdasarkan ikatan organisasi dan gerakan tertentu. Diantaranya adalah ikatan jaringan veteran Afghanistan. Pertukaran ide, gagasan dan pengalaman baru mereka di Malaysia, Afghanistan dan bahkan di Mindanao, Filipina Selatan menciptakan tradisi baru Islam yang cenderung pro-kekerasan. ${ }^{8}$ Menyebut sejumlah lulusan pesantren yang terlibat jaringan terorisme, seperti Ali Mukhlas, Fathurrahman Al-Ghazi, Amrozi dan Ali Imron setelah lulus dari Ngruki mereka menetap lama di Malaysia dan Afghanistan. Jadi, ada campurtangan dunia luar yang mempengaruhi dan mendoktrin para lulusan pesantren ini. Karena bertemu dan berkumpul dengan teroris, mereka akhirnya pun menjadi sadis dan mampu merakit bom untuk membunuh orang-orang yang tidak berdosa.

Disinilah letak pentingnya melakukan klarifikasi dari sejumlah imige negatif yang ditudingkan oleh sejumlah orang yang tidak bertanggung jawab terhadap pesantren. Dan penting bagi setiap kiai dan pengurus pesantren menunjukkan kepada khalayak akan arti penting pesantren sebagai wahana pencerdasan dan pemberdayaan masyarakat (empowering people), bukan penyebar paham radikalisme agama yang sangat menjadi musuh setiap kelompok agama. Tentu saja dengan usaha-usaha cerdas yang dapat menangkal dan membendung setiap gerakan dan jaringan terorisme di pesantren. Pertanyaan yang muncul kemudian adalah bagaimana agar gagasan ini dapat terwujud? Tulisan ini akan mencoba membahas dan memberikan sejumlah tawaran langkah-langkah yang bisa digunakan oleh pesantren untuk menangkal dan menutup infiltrasi terorisme dan radikalisasi agama yang sangat membahayakan bagi keberlangsungan kehidupan yang penuh kedamaian di muka bumi.

\section{B. Antara Radikalisme, Fundamentalisme \& Terorisme}

Semua orang pasti tahu, bahwa dampak teror New York "11 September 2001" dan menajam sejak teror Bali "12 Oktober 2002", adalah pencitraan negatif terhadap Islam, termasuk dunia pesantren. ${ }^{9}$ Pesantren yang pada mulanya terkenal sebagai

8 Badrus Saleh, Op Cit. hal: 4.

9 Mulai tragedi kemanusiaan 11 September 2001,- atas serangan yang melibatkan dua pesawat penumpang jet yang menghantam dan merobohkan menara kembar WTC (World Trade Center) di New York, dan dalam serangan lain di Washington,-hingga saat ini, sejarah dunia melukiskan 
suatu lembaga pendidikan Islam yang menjaga tradisi dan mengajarkan ilmu-ilmu agama serta akhlak bagi para santri, tiba-tiba harus dicurigai dan dituding ${ }^{10}$ sebagai "sarang teroris". Pesantren yang sebagian besar fiqh oriented dan mengutamakan ilmu-ilmu ukhrowi, tiba-tiba dilibatkan dalam persoalan duniawi yang amat asing. Bom, teroris, dan segala sesuatu yang bercorak superradikal.

Itulah dinamika dan tantangan pesantren kontemporer. Masyarakat pesantren pastilah shock berat dengan sejumlah tudingan yang dialamatkan kepada mereka. Bukan saja bingung harus berbuat apa dan bagaimana untuk mengatasinya, kebanyakan mereka mungkin tidak mengerti kosakata yang disematkan oleh Barat tersebut. Bukankah selama ini mereka sering mendengar terminologi yang sangat berlawanan dengan "istilah" yang menakutkan tersebut? Karena biasanya, mufradat yang sering mereka dengar adalah, tawaddlu'(hormat), tasamuh (toleran), ta'awun (saling tolong menolong), dan kata-kata sejenis lainya. Dengan penuh kedamaian para santri biasanya mengkaji kalam-kalam ilahi, mengharakati dan menerjemahkan kitab-kitab kuning yang dibaca para kiainya. Dan kutub al-turast yang dibaca kiai pesantren tersebut kebanyakan berisikan tuntutan dan anjuran bagaimana menjadi manusia yang saleh dan bermanfaat bagi masyarakat dan lingkungannya.

Lalu pertanyaanya adalah apakah sebenarnya makna istilah-istilah yang asing bagi para santri tersebut? Menurut pelacakan sejumlah referensi, sesungguhnya Istilah radikalisme lebih menunjukkan pada gerakan kekerasan yang diambil oleh sekelompok golongan akibat respon ketidakpuasan pada realitas politik dan sosiohistoris. Radikalisme tentu saja berbeda dengan fundamentalisme, sebab fundamentalisme biasanya dalam bahasa Arab disebut dengan usuliyyah berasal dari kata usul, yang merujuk pada prinsip-prinsip dasar yurisprudensi Islam (ushul

wajah Islam sebagai agama yang ekslusif dan menyeramkan. Islam dipahami sebagai agama yang anti globalisasi, anti peradaban, dan penebar api peperangan. Antipati Barat ditunjukkan dengan nyata terhadap penganut Islam, mulai pelarangan aktivitas kelompok-kelompok Islam yang dianggap radikal, pemberantasan jaringan-jaringannya, hingga ancaman-ancaman lain terhadap negara-negara yang mayoritas berpenduduk Islam. lihat Amir Mu'allim, "Mendalami Ide Islam Humanis", Dalam Jawa Pos, Jumat 24 Januari, 2003.

10 Streotipe Barat terhadap Islam, seperti ini, yang sering digambarkan sebagai agama yang antidemokrasi, tidak toleran, dan para pengikutnya digambarkan sebagai "fanatik" seperti itu, sebenarnya sudah lama berlangsung. Satrio Arismunandar menjelaskan, bahwa sejak awal 1970-an tanggapan dunia Barat dan media massanya terhadap Islam bersifat problematik dan antipatis. Kata Islam seringkali digunakan oleh media massa Barat dalam bentuk generalisasi yang kurang cermat atau untuk mengartikan sesuatu yang sangat disederhanakan. Lebih lanjut coba lihat Satrio Arismunandar, "Islam di Mata Media Massa Barat", dalam Jurnal Islamika, No 1 Juli-September, (Jakarta: MISSI \& Bandung: Mizan, 1993), hal. 64-67. 
fiqih). ${ }^{11}$ Seorang fundamentalis berarti adalah seorang yang mendasar atau lebih tepatnya keinginan mengembalikan segala sesuatu kepada asal pokoknya-dalam konteks Islam kembali kepada sumber hukum yaitu Al-Qur'an dan Al-Hadist. Tak salah jika karakter fundamentalisme oleh John L. Esposito, ${ }^{12}$ dicirikan dengan sifat "kembali kepada kepercayaan fundamental agama. Esposito tidak sepakat dengan seseorang yang mengartikan fundamentalisme secara sombrono disamakan dengan ekstrimisme, fanatisme, aktivisme politik, dan anti-Amerika.

Meskipun menurut Muhammad Imarah, ${ }^{13}$ pengertian fundamentalisme seperti itu, yang berarti tadjid berdasarkan pesan moral Al-Qur'an dan as-Sunnah berbeda dalam prespektif Barat. Sebab dalam pandangan Barat, Fundamentalisme berarti paham orang-orang kaku ekstrim serta tidak segan-segan berperilaku dengan kekerasan dalam mempertahankan ideologinya. Kalau yang dimaksud dengan fundamentalisme adalah seperti ini, sesungguhnya Islam sangat menentang ajaran-ajaran ektrimisme dan kekerasan apalagi sampai harus membunuh nyawa orang lain.

Kalau kemudian terjadi sebuah gerakan yang dilakukan oleh kelompokkelompok yang menamakan dirinya kelompok Islam dengan menggunakan sejumlah kekerasan, teror bom dan bunuh diri disejumlah negara termasuk di Indonesia, ini sesungguhnya merupakan fenomena yang jauh dari nilai-nilai Islam. Dan gerakan fundamentalisme dengan menggunakan jenis kekerasan seperti ini oleh Kuntowijoyo $^{14}$ diartikan sebagai radikalisme dan terrorisme serta mempunyai implikasi politik yang membahayakan bagi negara-negara industri di Barat.

Relevan dengan fundamentalisme yang menentang kebijakan-kebijakan Barat dan selalu mengekspresikan kekerasan dengan menunggangi agama seperti itu, sebetulnya menurut BassamTibi ${ }^{15}$ adalah fenomena global, fenomena yang dapat ditemui di semua agama besar dunia”. Lebih lanjut ia menjelaskan sesungguhnya fundamentalisme tidaklah menunjukkan keyakinan-keyakinan agama, tetapi lebih merupakan pandangan dunia sosio-politik. Ekspresi fundamentalisme bukanlah ekspresi kebangkitan agama, melainkan pernyataan tentang tatanan baru dengan menggantikan struktur-struktur

11 Karen Amstrong, "Islam : A short History" diterjemahkan oleh Fungky Kusnaedy Timur, (Yogyakarta: Jendela, 2005), Cetakan ke-5, hal.197.

12 John L. Esposito, Islam and State, (New York: Syracuse University Press, 1987), p. ix.

13 Muhammad Imarah, Fundamentalisme Dalam Perspektif Barat dan Islam, Terjemahan Abdul Hayyie al-Kattani, (Gema Insani Press, Jakarta, 1999), hlm.22.

14 Lihat Kuntowijoyo, Identitas politik Umat Islam, (Mizan,Bandung, 1997), hlm. 49.

15 LihatBassamTibi, Ancaman Fundamentalisme: Rajutan Islam Politik dan Kekacauan Dunia Baru, (Yogya: Tiara Wacana, 2000), hal. 22-23. 
yang ada dengan sistem yang komprehensif yang berasal dari agama, yang mencangkup hukum, politik, masyarakat, ekonomi dan budaya.

Gerakan fundamentalisme dengan melacak akar sejarahnya sebenarnya merupakan respon kekecewaan terhadap sekulerisme Barat dan tidak hanya fenomena Islam melainkan semua agama dengan karakteristik yang khusus. Sebab, setiap gerakan fundamentalisme mengekspresikan ketakutan terhadap modernisasi dan liberalisasi yang diusung Barat dan dianggap oleh mereka akan menghapus agama. Semua yang berbau Barat mereka haramkan dan selalu menampilkan gerakan-gerakan yang selalu dibungkus dengan keyakinan dan doktrin untuk menyedot perhatian publik dan membangkitkan emosi sejumlah pengikut serta siap mempertahankan dan menjadi tumbal sekaligus terhadap agama yang diyakininya.

Kalau melihat ke belakang, fundamentalisme pertama kali dikenal di Amerika Serikat,yang merupakan etalase modernitas, dan pada masa selanjutnya hanya muncul di bagian lain di dunia ini. Diantara agama monoteistik, Islam adalah agama terakhir yang mengembangkan nada fundamentalisme, ketika budaya modern mulai mengakar di dunia Muslim pada akhir 1960-an dan 1970-an. Pada masa ini, fundamentalisme sangat mapan di antara kalangan Kristen danYahudi, yang telah lama menikmati pengalaman modern. ${ }^{16}$ Kelompok fundamentalisme Islam yang kecewa terhadap Barat, melakukan usaha-usaha yang oleh Fazlur Rahman bukunya berjudul Islam and Modernity disebut dengan anti-pembaratan (westernisme). ${ }^{17}$

\section{Pesantren \& Varian Gerakan Islam Kontemporer}

Sebelum membahas tentang berbagai strategi dan gerakan yang dapat dipakai pesantren untuk membendung radikalisasi agama, alangkah baiknya terlebih dahulu mengerti tentang dinamika yang terjadi diseputar pesantren, terutama dengan munculnya berbagai varian pemahaman dan gerakan pasca reformasi. Hal ini untuk memberikan peta pemahaman, sekaligus warning bagi pesantren agar mampu membuat strategi dakwah yang jitu dan efektif dalam menghadapi dan menangkal setiap bentuk kekerasan yang mengatasnamakan agama. Sekaligus menyadarkan pada semua orang sesungguhnya, di luar pesantren pun telah terjadi tarik menarik dan perebutan massa atau pengikut oleh kelompok-kelompok keagamaan. Meskipun terkadang harus menimbulkan sejumlah ketegangan diantara mereka yang sama-

16 Karen Amstrong, "Islam : A short History" ,Op Cit, hal. 197.

17 Fazlur rahman, Islam And Modernity, (Chicago:The University of Chicago Press, 1982), p.136. 
sama memakai kopiah dan surban serta mengaku bersumber kepada Al-Qur'an dan Al-Hadist, dan tentu saja juga menimbulkan "kebingungan" untuk mengkatagorikan mana pesantren yang beraliran moderat dan garis keras.

Realitas tersebut menarik untuk dicermati dan akhirnya bisa disimpulkan bahwa era reformasi dengan segala agendanya, ternyata masih menyisakan problem tersendiri bagi masyarakat Indonesia. Diantaranya adalah gejala keagamaan di Indonesia kontemporer menunjukkan gejala-gejala yang saling "bertentangan" dengan citacita demokrasi ${ }^{18}$. Tuntutan otonomi individu, self expression, self realization, misalnya berbarengan dengan munculnya gejala komunalisme yang muncul di berbagai daerah. Gelombang spiritualisme pada saat yang sama juga berbarengan dengan semakin menguatnya gerakan formalisme agama, yang berujung pada perilaku anarkisme dan kekerasan.

Tidak bisa dipungkiri, pasca reformasi dengan agenda utamanya "demokratisasi" telah menyebabkan masyarakat Indonesia merasa dibuka dan diberi kebebasan untuk menyuarakan aspirasi pendapat dan politiknya, setelah sekian lama merasa dikebiri oleh pemerintah Orde Baru. Ditandai dengan keterbukaan, partai politik tumbuh bak cendawan di musim penghujan, organisasi budaya berkembang pesat, begitu juga dengan organisasi keagamaan. Semua berkembang dan mencoba mencari jati diri. Dalam hal organisasi keagamaan yang berkembang pesat adalah mereka yang berorientasi fundamentalis ${ }^{19}$, karena pada masa-masa sebelumnya mereka tidak bisa bergerak akibat kekuasaan otoriter orde baru yang selalu mencoba untuk memarginalkan mereka.

${ }_{18}$ Terdapat sejumlah nilai, norma dan etika yang merupakan ruh demokrasi, tanpa ini semua demokrasi menjadi semu. Mayo dalam bukunya An Introduction to Democratic Theory menyebutkan nilai demokrasi sebagi berikut: (1). Menyelesaikan perselisihan dengan damai dan secara sukarela (2). Menjamin terselenggaranya perubahan secara damai dalam suatu masyarakat yang sedang berubah (3). Menyelenggarakan pergantian pimpinan secara teratur (4). Membatasi pemakaian kekerasan (5). Mengakui serta mengganggap wajar adannya keberbagian dalam masyarakat (6). Menjamin tegaknya keadilan; dan (7) adanya nilai-nilai yang dihasilkan oleh kelemahan-kelemahan sistem yang lain. Sementara Cunningham memberikan ciri-ciri demokrasi sbb; pemeliharaan situasi yang damai, adanya kepemimpinan yang baik dan berpengaruh; wisdom; stabiltas; legitimasi; kesejahteraan; keadilan sosial; persamaan; dan kemerdekaan yang positif. Lihat F. Cunningham, Theories of Democracy: $A$ Critical Introduction, (New York: Routledge, 2002), p. 149-162.

19 Sebagaimana pelacakan dari beberapa referensi, fundamentalis adalah termasuk dalam gerakan revivalis dan ide dasarnya adalah kembali ke ajaran Islam yang benar sebagaimana yang dipraktekkan oleh kaum salaf al-shahih. Kekalahan Islam dari Barat dipandang sebagai akibat dari ditinggalkannya ajaran Islam yang benar. Agar kembali mencapai kejayaannya, umat Islam harus kembali kepada ajaran yang telah mampu mengangkat umat Islam mencapai kejayaannya pada masa lampau. Untuk persoalan seperti ini bisa dilihat dalam James P. Piscatori, Islam in a World of Nation-State, (New York. etc.: Cambridge Univercity Press. 1988). p. 119-120. 
Sebagaimana analisis para ahli, sebenarnya gerakan Islam pasca reformasi terbagi menjadi beberapa varian pemikiran dan gerakan. Semuanya bisa dipetakan dan ditelusuri akar-akarnya menjadi dua arus pemikiran utama yang sangat dominan yakni literalisme dan liberalisme. ${ }^{20}$ Kelompok Islam literal biasanya mengusung ide-ide dan pemahaman keislaman yang “eksklusif”. Sedangkan kelompok liberalisme lebih terbuka, dan meminjam terminologi Kurzman ${ }^{21}$ diukur berdasarkan enam state of mind, yakni sikap terhadap teokrasi, demokrasi, hak-hak perempuan, hakhak non-muslim, kebebasan berpikir, dan progresifitas atau kemajuan.

Kedua kelompok tersebut memang telah memberikan "warna” tersendiri bagi kehidupan beragama dan bernegara di Indonesia. Kita bisa menyaksikan banyak sekali gerakan-gerakan Islam yang muncul dan menegaskan identitas mereka masingmasing. Menariknya baik kelompok-kelompok yang masuk dalam katagori literalisme maupun liberalisme, sama-sama kecewa dengan ormas-ormas besar seperti NU dan Muhammadiyah. ${ }^{22}$ Kalau kelompok literalis menggangap kedua organisasi besar ini tidak tegas dalam memperjuangkan aspirasi Islam. Sedangkan kelompok yang masuk dalam katagori liberalis menganggap NU dan Muhammadiyah sudah mulai kurang responsif terhadap isu-isu baru.

Untuk menyebut contoh-contoh yang termasuk dalam katagori Islam literalis ${ }^{23}$ adalah Hizbut Tahrir Indonesia (HTI), Majelis Mujahidin Indonesia (MMI), Front Pembela Islam (FPI), Laskar Jihad (LJ), dan Kesatuan Aksi Mahasiswa Muslim Indonesia (KAMMI). Model pemikiran gerakannya adalah adanya legalisasi Islam dalam sistem sosial ataupun politik Indonesia. Sedangkan yang termasuk dalam

20 Untuk pengelompokan gerakan Islam menjadi dua kelompok seperti ini bisa dilihat dalam Muhsin Jamil, Membongkar Mitos Menegakkan Nalar: Pergulatan Islam Liberal versus Islam Literal, (Yogyakarta:Pustaka Pelajar, 2005).

21 Charles Kurzman, Wacana Islam Liberal: Pemikiran Islam Kontemporer tentang Isu-isu Global, (Paramadina, 2001), hal. xiiv

${ }^{22}$ Coba bandingkan analisis munculnya ormas-ormas pasca reformasi oleh Ahmad Gauf AF, "Islam Progresif: Wacana Pasca Arus Utama", dalam Jurnal Taswirul Afkar, (Edisi No. 22 Tahun 2007).

${ }^{23}$ Organisasi yang termasuk dalam kelompok ini sering disebut sebagai "Gerakan Islam Baru" (New Islamic Movement) dan asal muasal pemikiranya dari berbagai gerakan Islam di Timur Tengah. Yang nyata-nyata mengimpor pemikiran dari Timur Tengah adalah gerakan Tarbiyah yang dekat dengan Ihwanul Muslimin (IM), Hizbut Tahrir Indonesia merupakan cabang dari HizbutTahrir International yang berpusat di Yordania dan kelompok Salafi termasuk Lasykar Jihad Ahlussunnah wal Jama'ah dan merupakan himpunan aktivis Dakwah Salafi yang berjejaring dengan gerakan Salafi di Timur Tengah, khususnya Arab Saudi dan Kuwait . lihat M.Imdadun Rahmat, Arus Baru Islam Radikal, (Jakarta: Erlangga, 2005), hal. 75. 
Islam Liberalis adalah JIL (Jaringan Islam Liberal), Post-Tra (Post-Tradisionalisme) dan JIMM (Jaringan Intelektual Muda Muhammadiyah).

Munculnya kelompok-kelompok agama dengan varian dan modelnya seperti tersebut di atas, sebenarnya adalah sah-sah saja. Asal semua masih dalam kontek NKRI dan koridor demokrasi. Tanpa ada inisisiatif memvonis keberadaan "mereka", barangkali fenomena di atas menunjukkan gejala signifikan yang harus direspon oleh umat Islam. Dan perlu dipahami, kebangkitan kaum "fundamentalis" sebenarnya bukanlah sebuah ancaman serius bagi kelompok atau golongan lain. Hanya saja, fenomena kekerasan beragama di Indonesia baru-baru ini, memang jika kita telusuri di samping karena alasan politis, juga karena motivasi-motivasi keagamaan para kaum fundamentalis, seperti jihad, yang mengakibatkan adanya tindakan-tindakan yang mengancam masa depan umat Islam itu sendiri. ${ }^{24} \mathrm{Kalau}$ hal ini dibiarkan tak menutup kemungkinan akan menimbulkan citra buruk bagi perkembangan Islam di Indonesia terutama pesantren yang selama ini terkenal dengan sikapnya yang lentur dan inklusif.

Di samping itu, masih banyaknya masyarakat yang belum mengerti betul hakikat dan sejatinya demokrasi sebenarnya adalah kondisi yang sangat menghawatirkan dan perlu segera dicarikan jalan keluarnya. Tak jarang, disinilah sebetulnya letak titik rawannya, karena banyak sekali kelompok-kelompok kegamaan tertentu dengan dalih menyuarakan aspirasi yang mewakili dari kelompok mayoritas, terkadang harus menimbulkan ketidak adilan dan diskriminasi terhadap kelompok minoritas ${ }^{25}$. Akibatnya adalah, tension atau ketegangan dan konflik kepentingan diantara masyarakat yang memiliki keanekaragaman agama, etnis dan budaya.

24 Sebab kalau kita menyaksikan akibat maraknya gejala kekerasan beragama selama ini, dan ini sungguh sangat aneh, buntut dari fenomena kekerasan atas nama agama, Islam banyak dituding oleh Barat sebagai biang keladi dari setiap ektrimisme, anarkisme dan terorisme. Padahal sejatinya, Islam syarat dengan ajaran kasih sayang dan cinta kasih. Islam memiliki ajaran fundamental seperti; pluralisme, humanisme dan demokarasi.

25 Sampai saat ini, sepertinya tidak terdapat definisi yang tunggal mengenai apa yang disebut sebagai minoritas atau kelompok minoritas. Dalam konteks Indonesia, terminologi minoritas bukan hanya sulit untuk menentukan definisinya secara ketat melainkan juga pada tataran batasan jumlahnya secara cacah jiwa. Bahkan dalam beberapa hal yang sangat konkret, kategorisasi minoritas yang disematkan oleh Negara terhadap kelompok tertentu tidak jarang menimbulkan reaksi balik yang cukup mengagetkan. Tetapi batasan minoritas kita bisa merujuk suatu definisi sebagai berikut: "A group of citizens of a State, constituting a numerical minority and in a non-dominant position in that State, endowed with ethnic, religious and linguistic characteristics which differ from those of the majority of the population, having a sense of solidarity with one another, motivated, if only implicitly, by a collective will to survive and whose aim is ti achieve equality with the majority in fact and in law. Lihat dalam Proposal Concerning a Definition of the Term 'Minority'UN Document E/CN.4/Sub.2/1985/31 (1985). 


\section{Ekspresi Keagamaan Islam Radikal}

Munculnya berbagai macam kelompok keagamaan yang sedang marak dan cenderung radikal khususnya di Indonesia pada abad ini, sesungguhnya bukanlah suatu fenomena yang muncul tanpa sebab. Gerakan-gerakan yang mereka lakukan pada prinsipnya merupakan ekspresi terdalam atas sebuah iman dan pemahaman terhadap agama yang diyakini kebenaranya. Parahnya, keyakinan tersebut berbuntut dengan dorongan untuk memperjuangkan agama yang diyakini kebenaranya itu kepada orang lain, kalau perlu dengan mengorbankan jiwa dan harta bendanya. Tujuan utama mereka adalah menyingkirkan dan membunuh orang-orang yang dianggap kafir dimuka bumi ini dengan harapan masuk surga.

Pemahaman kelompok Islam radikal biasanya cenderung totalistik dan formalistik. Dalam memahami teks-teks agama bersifat kaku dan rigid, dan harus sesuai atau sama dengan keadaan dan perilaku Nabi di Mekah dan Madinah. Bagi mereka, konteks sosial, politik, ekonomi dan budaya yang melingkupi umat Islam bukan merupakan pertimbangan penting. Sehingga, yang berlaku adalah zero tolerance terhadap khazanah tradisi lokal, sekaligus memusuhi intelektualisme yang bersumber dari dunia lain khususnya Barat. ${ }^{26}$

Selain disebabkan oleh faktor keimanan, fenomena radikalisasi agama menurut almarhum Gus Dur sebetulnya juga disebabkan oleh kegagalan umat Islam untuk memahami sifat Islam yang sebenarnya dan hal ini yang memungkinkan berlanjutnya radikalisasi Muslim di seluruh dunia. Untuk itu, diperlukan cara yang paling efektif untuk mengatasi ekstremisme Islam dengan menjelaskan apa yang benar-benar Islam untuk muslim dan non-Muslim. ${ }^{27}$ Kalau tidak menginginkan adanya mispersepsi dan salah pemahaman terhadap Islam sebagai agama pembawa kesejukan dan penebar kedamaian.

Lebih lanjut selain bermimpi masuk nirwana, penegakan Syariah dan menjaga Aqidah secara benar, sangat diyakini oleh kelompok radikal dapat mengantarkan kejayaan peradaban Islam. Mereka sama-sama berangkat dari keprihatinan terhadap kondisi umat saat ini. Lebih-lebih sebagaimana penjelasan BassanTibi, Islam radikal menganggap kekacauan dunia ini akibat sistem demokrasi yang dianut oleh mayoritas masyarakat dunia. Oleh karenannya sistem demokrasi ini dianggap sebagai kufr/heresty dan sebagai gantinya kelompok Islam radikal menawarkan gagasan

${ }^{26}$ M. Imdadun Rahamat, Arus Baru Islam Radikal, (Jakarta: Erlangga, 2005), hal.155.

27 KH Abdurrahman Wahid, dalam (The Wall Street Journal, 30/12/2005). 
hakimiyyat Allah/kekuasaan Tuhan sebagai alternatif. ${ }^{28}$ Karena sistem pemerintahan Tuhan di bangun dengan landasan Iman dan diyakini membawa tatanan dunia yang lebih baik.

Salah satu bentuk kekacauan dunia adalah yang terjadi di Indonesia. Meskipun mayoritas penduduknya beragama Islam, akibat menganut pemerintahan yang tidak Islami selalu mengalami keterbelakangan baik secara mental, maupun ekonomi. Bahkan sering terjadi ketidakadilan yang dialami umat Islam dan adanya gerakangerakan lokal dan global yang mengancam nilai-nilai akidah (keimanan) umat Islam. Oleh sebab itu, fenomena ini telah menggugah kesadaran mereka untuk memperjuangkan martabat bangsa ini dan berjuang dalam rangka amar ma'ruf nahi munkar. Upaya pembelaan umat Islam secara terorganisasi dengan gerakangerakan radikal ini dianggap mereka sebagai sesuatu hal mendesak yang perlu dilakukan karena globalisasi yang ada saat ini sudah menjelma menjadi penjajahan gaya baru, melalui upaya-upaya pemaksaan sistim politik, budaya dan sosial ke bangsa Indonesia yang mayoritas beragama Islam.

Jihad oleh kelompok mereka biasanya dipandang sebagai panggilan jiwa untuk selalu membela Islam. Jihad yang secara lughowi berarti "bersungguh-sungguh dan berupaya keras" ${ }^{29}$ bisa berarti oleh kelompok radikal dimaknai sampai kepada qital fi sabilillah. Jihad yang berarti "perang suci" ini, kalau secara nyata-nyata Islam diganggu oleh kelompok lain. Diganggu ini pengertianya banyak, seperti; agama Islam diserang, diejek dan dinodai. Atau mungkin umat Islam tidak diganggu tetapi, Allah dan nabinya diganggu. Maka kita sebagai umat Islam memiliki kewajiban bersama untuk menyerukan kata "jihad".

Tentang hukum jihad secara jelas, prespektif kelompok Islam Radikal biasanya sangat terpengaruh dengan bacaan mereka dalam memahami konsep jihad yang terdapat dalam ayat-ayat al-Qur'an ${ }^{30}$ seperti: Orang-orang yang beriman dan berhijrah

28 Meskipun harus diakui gagasan tentang pemerintahanTuhan/ hakimiyyat Allah yang diatawarkan para Fundamentalis Islam sebagai alternatife global terhadap Negara sekuler, justru membuat lebih buruk divisi-divisi manusia dalam peradaban-peradaban. Politik-politik fundamentalis juga mencabik-cabik tatanan populasi Negara multiagama dan multietnis. Lihat BassamTibi, Op Cit. hal: 44.

29 Lihat pengertian jihad dalam Mohammad Said Al-Asmawy, Jihad Melawan Islam Ekstrem", (Jakarta: Desentara, 2002), hal. 47.

30 Tentang makna Jihad dalam al-Qur'an terdapat berbagai perbedaan arti. Adakalanya jihad berarti menjaga iman dan kehormatan seseorang di tengah-tengah situasai yang gawat. Seperti dalam perintah Allah kepada nabi agar bersikap sabar terhadap orang-orang Mekkah, bersikap tenang, dan tidak melayani kekuatan dengan kekuatan, lihat dalam Surat 88: 22, Surat 29: 18 dan Surat 103: 3. 
serta berjihad di jalan Allah dengan harta dan jiwa mereka (mereka mendapatkan) derajat yang paling mulia di sisi Allah dan menrekalah orang-orang yang berbahagia.Allah meberi kabar gembira bahwa mereka mendapat rahmat dari pada Nya, mendapat keridhoan dan syurga yang di dalamnya penuh dengan kenikmatan yang kekal abadi, sesungguhnya Allah memiliki pahala yang besar (QS 9:20-22).

Memang telah terjadi perbedaan yang sangat menonjol di kalangan umat Islam terhadap implementasi penegakan syari'ah dan pendirian negara Islam atau sering disebut dengan daulah Islamiyah dengan sistem khilafah. Diantara kelompokkelompok Islam terdapat beberapa kelompok yang secara terang-terangan menyebutkan aktivitas dan gerakannya untuk membentuk sistem pemerintahan dengan sistem khilafah ini ${ }^{31}$, namun tak sedikit dari mereka yang justru menolak ide pendirian Daulah Islamiyah. Dengan beragam dalil dan tafsir mereka gunakan sebagai landasan untuk memperkuat pemikiran masing-masing.

Berbeda dengan kelompok Islam radikal tentang hukum pendirian negara atau pemerintahan khilafah adalah kelompok Islam yang biasanya beraliran Aswaja. Sebab aswaja oleh kelompok ini memandang pendirian khilafah adalah fardlu kifayah. Sikap politik sunni ini, menurut Aqil Siradj32 adalah suatu sikap moderat yang mencoba menjembatani dua pandangan kelompok ekstrim, yakni antara kaum syi’ah yang menjadikan keberadaan pemerintahan merupakan sebagai rukun imam dan kaum khawarij yang memperbolehkan adanya komunitas pemerintahan vakum.

Kelompok Islam radikal berpandangan sesungguhnya Islam berarti kepatuhan kepada kehendak-kehendak Allah dan taat hukum-hukum-Nya, dan karena itu adalah inti dari setiap pesan dan ajaran yang disampaikan Allah malalui utusan-utusanNya, maka seorang muslim selalu menerima seluruh nabi sebagaiman mereka menerim Nabi Muhammad Saw. tanpa adanya rasa diskriminasi. Dia percaya bahwa seluruh Rasul yang telah diutus oleh Allah, dan para pengikutnya adalah muslim seperti mereka juga, dan bahwa agama mereka juga Islam, satu-satunya agama yang benar-benar universal dari Allah (Qur'an 2: 128-140; 3: 78-85; 17: 42-44;31 :22;42;13).

Lalu pada fase Madinah (622-632 M), kata Jihad mencakup perjuangan individu atau masyarakat dengan orang-orang Mekkah. Pada periode inilah jihad berarti perang Suci. Lihat dalam Surat 29: 69, artinya:" Barang siapa bersungguh-sungguh berjuang di jalan kami (Tuhan), maka kami akan menunjukkan kepada mereka jalan kami". Dan Surat 25: 52, artinya: "Janganlah tunduk kepada orang-orang yang tidak beriman, tetapi berjuanglah melawan mereka sebenar-benar jihad".

31 Untuk menyebut salah satu kelompok ini adalah HTI (Hizbut Tahrir Indonesia).

32 Said Aqiel Siradj, Islam Kebangsaan: Fiqih Demokartik Kaum Santri, (Jakarta: Pustaka Ciganjur, 1999), hal. 74. 
Oleh sebab itu, sesungguhnya persoalan Syariah Islamiyah bagi kelompok Islam radikal merupakan "harga mati" yang akan selalu diwujudkan dan diperjuangkan pelaksanaanya di Indonesia. Mereka memandang Syariah adalah satu-satunya nizdamul Islam yang di dalamnya terkandung segala perintah yang telah diperintahkan oleh Allah SWT dan larangan-larangan yang telah dilarang oleh Allah. Jadi kata Syari'ah digunakan untuk pengertian hukum-hukum Allah yang diturunkan untuk manusia. Syariah merupakan salah satu perkara yang sangat penting dalam Islam. Dengan syariat dapat diwujudkan kemaslahatan umat baik di dunia maupun di akhirat. Sebab dalam keyakinan mereka, syariat atau ajaran Islam bukan hanya mengenai satu segi saja dari kehidupan manusia melainkan meliputi seluruh aspek kehidupan, seperti yang berkenaan dengan aspek keimanan, peribadatan, akhlak sejarah, kebudayaan dan ilmu pengetahuan.

\section{E. Pengajaran Aqidah Inklusif: Usaha Membendung Radikalisme Agama}

Setelah memahami varian gerakan Islam seperti tersebut di atas dan munculnya sejumlah kelompok Islam radikal dengan motif untuk mendirikan pemerintahan Islam di Indonesia. Langkah awal yang perlu segera dilakukan oleh pesantrenyang selama ini terkenal sebagai penjaga Pancasila yang tangguh-untuk menangkal merembesnya jaringan radikalisme agama. Pesantren dalam konteks ini, harus berorientasi melahirkan santri yang berwawasan multikultural dengan mengajarkan Aqidah yang inklusif dan terbuka dengan Aqidah keberagamaan lain, bahkan kalau perlu melakukan interfaith dialog.

Hal tersebut mutlak diperlukan sebab, sebagaimana telah banyak diketahui umat Islam, aqidah berasal dari bahasa Arab yang berarti "kepercayaan", maksudnya ialah hal-hal yang diyakini oleh orang-orang beragama. Dalam Islam, aqidah selalu berhubungan dengan iman. Aqidah adalah ajaran sentral dalam Islam dan menjadi inti risalah Islam melalui Muhammad SAW. Tegaknya aktivitas keislaman dalam hidup dan kehidupan seseorang itulah yang dapat menerangkan bahwa orang itu memiliki akidah.

Masalahnya karena iman itu bersegi teoritis dan ideal yang hanya dapat diketahui dengan bukti lahiriah dalam hidup dan kehidupan sehari-hari, terkadang menimbulkan "problem" tersendiri ketika harus berhadapan dengan "keimanan" dari orang yang beragama lain. Apalagi persoalan iman ini, juga merupakan inti bagi semua agama, jadi bukan hanya milik Islam saja. Maka, tak heran jika kemudian 
muncul persoalan truth claim dan salvation claim diantara agama-agama, yang sering berakhir dengan konflik antar agama.

Untuk mengatasi persoalan seperti itu, pendidikan pesantren melalui ajaran aqidahnya, perlu menekankan pentingnya "persaudaraan” umat beragama. Meminjam bahasanya Amin Haedari "pesantren harus membuka diri dengan masyarakat (inklusif), toleran dan hanif. Mengingat pemahaman corak ini tidak kaku dalam memahami Al-Qur'an dan Al-Hadist. ${ }^{33}$ Pelajaran aqidah, bukan sekedar menuntut pada setiap santri menghapal sejumlah materi yang berkaitan denganya, seperti iman kepada Allah swt, nabi Muhamad saw, dll. Tetapi sekaligus, menekankan arti pentingya penghayatan keimanan tadi dalam kehidupan sehari-hari. Intinya, aqidah harus berbuntut dengan amal perbuatan yang baik atau akhlak al-Karimah pada peserta didik. Memiliki akhlak yang baik pada Tuhan, alam dan sesama umat manusia.

Pesantren harus segera sadar, bahwa kerusuhan-kerusuhan bernuasan SARA seperti yang sering terjadi di Indonesia ini adalah akibat ekspresi keberagamaan yang salah dalam masyarakat kita, seperti ekspresi keberagamaan yang masih bersifat ekslusif dan monolitik serta fanatisme untuk memonopoli kebenaran secara keliru. Celakanya, ekspresi keagamaan seperti itu merupakan hasil dari "pendidikan agama”. Pendidikan agama dipandang masih banyak memproduk manusia yang memandang golongan lain (tidak seakidah) sebagai musuh. Maka di sinilah perlunya menampilkan pendidikan agama di pesantren yang fokusnya adalah bukan semata kemampuan ritual dan keyakinan tauhid, melainkan juga akhlak sosial dan kemanusiaan.

Pesantren yang merupakan salah satu pendidikan agama diIndonesia, tentu saja sebagai salah satu sarana yang sangat efektif untuk menginternalisasi nilai-nilai atau aqidah inklusif pada para santri. Perbedaan agama di masyarakat seharusnya dapat dijadikan sebagai mitra untuk berdialog, bukan malah menjadi penghalang untuk bisa bergaul dan bersosialisasi diri. Justru pesantren yang dapat bergaul dengan agama lain yang berbeda aqidah, dapat dijadikan sarana untuk menggali dan menemukan nilai-nilai keagamaan pada agamanya masing-masing sekaligus dapat mengenal tradisi agama orang lain.

Target pendidikan agama di pesantren harus berorientasi pada akhlak. Bahkan dalam pengajaran akidahnya, kalau perlu semua peserta didik disuruh merasakan jadi orang yang beragama lain atau atheis sekalipun. Tujuanya adalah bukan untuk

${ }^{33}$ HM. Amin Haedari, et al., Masa Depan Pesantren: Dalam Tantangan Modernitas dan Kompleksitas Global, (Jakarta:IRD Press, 2004), hal.234. 
"konfersi", melainkan dalam rangka agar mereka mempertahankan iman. Sebab, akidah itu harus dipahami sendiri, bukan dengan cara taklid, taklid tidak dibenarkan dalam persoalan akidah. Selain itu, pada masalah-masalah syari'ah. Dalam persoalan syariah, sering umat Islam juga berbeda pendapat dan bertengkar. Maka dalam hal ini pesantren perlu memberikan pelajaran "fiqih muqarran" untuk memberikan penjelasan adanya perbedaan pendapat dalam Islam dan semua pendapat itu samasama memiliki argumen, dan wajib bagi kita untuk menghormati.

Pesantren harus memandang "iman", yang dimiliki oleh setiap pemeluk agama, bersifat dialogis artinya iman itu bisa didialogkan antara Tuhan dan manusia dan antara sesama manusia. Iman merupakan pengalaman kemanusiaan ketika berintim dengan-Nya (dengan begitu, bahwa yang menghayati dan menyakini iman itu adalah manusia, dan bukanya Tuhan), dan pada tingkat tertentu iman itu bisa didialogkan oleh manusia, antar sesama manusia dan dengan menggunakan bahasa manusia.

Tujuan untuk menumbuhkan saling menghormati kepada semua manusia yang memiliki iman berbeda atau mazhab berbeda dalam beragama, salah satunya bisa diajarkan lewat pendidikan akidah yang inklusif. Dalam pembelajaranya, tentu saja memberikan perbandingan dengan akidah yang dimiliki oleh agama lain (perbandingan agama). Meminjam bahasanya Alex Roger ${ }^{34}$, pendidikan akidah seperti itu mensyaratkan adanya fairly and sensitively dan bersikap terbuka (open minded). Tentu saja, pengajaran agama seperti itu, sekaligus menuntut untuk bersikap "objektif" sekaligus "subjektif". Objektif, maksudnya sadar bahwa membicarakan banyak iman secara fair itu tanpa harus meminta pertanyaan mengenai benar atau validnya suatu agama. Subjektif berarti sadar bahwa pengajaran seperti itu sifatnya hanyalah untuk mengantarkan setiap peserta didik memahami dan merasakan sejauh mana keimana tentang suatu agama itu dapat dirasakan oleh orang yang mempercayainya.

Melalui pengajaran akidah inklusif seperti itu, tentu saja bukan untuk membuat suatu kesamaan pandangan, apalagi keseragaman, karena hal itu adalah sesuatu yang absurd dan agak mengkhianati tradisi suatu agama. yang dicari adalah mendapatkan titik-titik pertemuan yang dimungkinkan secara teologis oleh masingmasing agama. setiap agama mempunyai sisi ideal secara filosofis dan teologis, dan inilah yang dibanggakan penganut suatu agama, serta yang akan menjadikan mereka

${ }^{34}$ Alex R. Rodger, (1982), Educational and Faith in Open Society, (Britain: The Handel Press.), P. 61-62. 
tetap bertahan, jika mereka mencari dasar rasional atas keimanan mereka. Akan tetapi, agama juga mempunyai sisi real, yaitu suatu agama menyejarah dengan keagungan atau kesalahan-kesalahan yang biasa dinilai dari sudut pandang sebagai sesuatu yang memalukan. Oleh karena itu, suatu dialog dalam perbandingan agama harus selalu mengandalkan kerendahan hati untuk membandingkan konsep-konsep ideal yang dimiliki agama lain yang hendak dibandingkan, dan realitas agamabaik yang agung atau yang memalukan-dengan realitas agama lain yang agung atau memalukan itu dengan demikian, akan dapat terhindar dari suatu penilai stndar ganda dalam melihat agama lain.

\section{F. Reformulasi Kurikulum Multikultural di Pesantren}

Telah disebutkan dimuka, pasca kekerasan agama di Indonesia telah menimbulkan citra buruk terhadap pesantren. Sebuah pendidikan Islam yang biasanya berorientasi untuk tafaqquh fid-din ini, tiba-tiba dituding sebagai "biang keladi" dengan adanya sejumlah pengeboman di sejumlah tempat di Indonesia dan gerakan super-radikal lainya. Imige yang tidak menyenangkan ini, tentu saja harus direspon dengan bijaksana oleh setiap kiai atau pemimpin pesantren.

Bahkan lebih baik semua prasangka tersebut perlu direspon dengan cara-cara yang edukatif dan santun, sembari mengintropeksi diri dan mengevaluasi kemungkinan-kemungkinan yang selama ini dianggap bisa menimbulkan kesalahpahaman antara Islam dengan non-Islam. Untuk tujuan mulia ini, tentu saja para kiai dan pengasuh pondok pesantren dituntut untuk berfikir kritis serta melakukan reformasi kurikulum pesantren, ${ }^{35}$ dengan menekankan pada upaya rekontruksi, pada konteks ke-Indonesia-an, dengan mempertimbangkan kondisi masyarakat yang sedemikian plural, baik agama, etnis, maupun kepercayaan.

Paradigma pendidikan agama dalam pesantren yang cenderung kaku, yang menekankan pada formalitas agama hendaknya dapat dikendorkan agar out-put yang dihasilkan dapat menjadi generasi yang tidak memusuhi agama, karena

35 Perlu kiranya merubah paradigma pendidikan pesantren yang cenderung kaku, yang menekankan pada formalitas agama hendaknya dapat dikendorkan agar out-put yang dihasilkan menjadi generasi yang tidak memusuhi agama, karena menganggap orang-orang tidak taat agama dan menuduh ilmu-ilmu Barat sebagai ilmu-ilmu kafir. Hendaknya ponpes bersifat dinamis sesuai dengan perkembangan zaman, asalkan maih dalam koridor syari'at Islam dan tidak menyalahi sunnahnya. Sehingga apa yang namanya perbedaan sebagai rahmatan lil alamin benar-benar ada dalam kehidupan ini. 
menampilkan perilaku-perilaku yang bertentangan dengan ajaran prinsip agama. Pendidikan agama di pesantren harus bersifat dinamis sesuai dengan perkembangan jaman, asalkan masih dalam koridor syrai'at Islam dan tidak menyalahi sunnahnya. Sehingga apa yang namanya perbedaan sebagai rahmatan lil alamin benar-benar ada dalam kehidupan ini. Dalam konteks ini perlu kiranya mengajarkan paham multikulturalisme dan pluralisme di pesantren.

Paham multikultural tersebut penting untuk diperkenalkan dipesantren sebab dianggap mampu membawa kesadaran bagi para santri atau masyarakat pesantren agar dapat membuka visi pada cakrawala yang semakin luas, mampu melintas batas kelompok etnis atau tradisi budaya dan agama mereka sehingga mereka mampu melihat "kemanusiaan" sebagai sebuah keluarga yang memiliki baik perbedaan maupun kesamaan cita-cita. Inilah sebuah kurikulum pendidikan akan nilai-nilai dasar kemanusiaan untuk perdamaian, kemerdekaan, dan solidaritas.

Orientasi penanaman multikulturalisme di pesantren, tentu saja hanya pada proses penyadaran yang berwawasan pluralis secara agama sekaligus berwawasan multikultural. Dalam konteks Indonesia yang majemuk, ini penting untuk direalisasikan sebab pesantren yang telah menanamkan paham multikulturalisme, dapat dilihat sebagai bagian dari upaya komprehensif mencegah dan menaggulangi konflik etnis agama, radikalisme agama, separatisme, dan integrasi bangsa, sedangkan nilai dasar dari konsep multikulturalisme ini adalah toleransi.

Melalui pengenalan dan penanaman konsep multikultural di pesantren, seseorang santri bisa diantarkan untuk dapat memandang pluralitas keindonesiaan dalam berbagai aspek sosial, ekonomi, politik, budaya, dan agama sebagai kekayaan spritual bangsa yang harus tetap dijaga kelestarianya. Akhirnya, diharapkan mampu memberikan dorongan terhadap penciptaan perdamaian dan upaya menanggulangi konflik, sebab nilai dasar dari pendidikan multikultural adalah penanaman dan pembumian nilai toleransi, empati, simpati, dan solidaritas sosial.

Untuk mendukung pencapaian kurikulum pendidikan multikulturalisme di pesantren, semua aspek kelembagaan dan proses belajar mengajarnya harus menerapkan sistem dan metode yang dapat menumbuhkan multikulturalisme serta mampu menggali sisi perdamaian dan toleransi. Pesantren dalam hal ini, tentu saja harus mampu mengedepankan para santri untuk dapat mengapresiasi dialog antaragama, kemudian melatih mereka guna menyelenggarakan pelbagai dialog secara mandiri, sekaligus dapat menghimpun berbagai pemikiran dan pandangan dari berbagai kalangan yang memiliki kepedulaian terhadap peran agama dalam memecahkan problem sosial yang ada. 
Pertimbangan lain yang perlu diperhatikan oleh pesantren dalam menanamkan konsep multikultural adalah bahwa sekarang mereka hidup dalam era globalisasi. Oleh karena itu, mustahil sebuah negara hanya terdiri atas satu budaya, etnis, suku atau aliran (agama) saja. Kemajuan tehnologi, informasi, dan transportasi telah melampaui batas-batas negara. Hal ini menyebabkan sebuah negara tak mungkin terisolasi dari pergaulan dunia.

Melihat realitas seperti itu, maka sikap menghormati dan menghargai bahkan menjunjung tinggi harkar martabat semua orang adalah sikap yang sangat penting. Perlakuan dan penghormatan yang sama harus diaplikasikan dalam seluruh aspek kehidupan, termasuk dalam bidang pendidikan agama.

Relevan dengan kenyataan tersebut, Intinya bahwa seharusnya yang menjadi tujuan refleksi pendidikan pesantren adalah harus mampu melakukan tranformasi kehidupan beragama itu sendiri dengan melihat sisi ilahi dan sosial budayanya. Pesantren harus berusaha menjaga kebudayaan suatu masyarakat dan memindahkanya kepada generasi berikutnya, menumbuhkan akan tata nilai, memupuk persahabatan antar siswa yang beraneka ragam suku, ras, agama, mengembangkan sikap saling memahami, serta mengerjakan keterbukaan dialog.

Untuk bisa melakukan dialog antar-agama yang mampu menghasilkan prinsip saling menghormati dan menyayangi serta memajukan kebaikan sesama manusia diperlukan "kesadaran mistika". Oleh sebab itu-untuk menghantarkan para santri memimiliki kesadaran mistika ini-pendididikan di pesantren harus meletakkan para santri pada proses dialektika sejarah yang panjang. Ia harus dapat menghantarkan mereka melalui berbagai tingkat kesadaran. Tidak boleh ada satu tahap kesadaran yang dinafikan, termasuk kesadaran mistika ini.

Selain hal tersebut, dalam proses pendidikannya, pesantren perlu menekankan pada konsep unity in diversity. Disertai suatu sikap, dengan tidak saja mengandaikan suatu mekanisme berfikir terhadap agama yang tidak monointerpretble, atau menanamkan kesadaran bahwa keragaman dalam hidup sebagai suatu kenyataan, tetapi juga memerlukan kesadaran bahwa moralitas dan kebajikan bisa saja lahir (dan memang ada) dalam konstruk agama-agama lain. Tentu saja, penanaman konsep seperti ini dengan tidak mempengaruhi kemurnian masing-masing agama yang diyakini kebenaranya oleh para santri.

\section{G. Penutup}

Sudah seharusnya pesantren melakukan berbagai upaya untuk merespon dan menjawab segala macam tantangan di era globalisasi sekarang, termasuk maraknya 
radikalisasi agama yang berbuntut pencemaran nama baik pesantren karena dianggap sebagai sarang teroris. Hal penting yang perlu segera direalisasikan pesantren adalah pembenahan paradigma dan kurikulumnya demi menyahuti tuntutan globalisasi. Demi survivalitasnya, disamping harus selalu menjaga tradisi yang menjadi karakternya-pesantren dituntut untuk bisa membuka diri dengan dunia luar (open minded), agar mampu beriteraksi sekaligus memberi tawaran-tawaran cerdas berbasis nilai-nilai religious yang sangat dinanti oleh masyarakat luas.

Berbekal penanaman aqidah inklusif dan pemahaman akan pluralitas, para santri pasti mampu secara fleksibel bergaul dan bersaing dengan orang lain yang berbeda agama, etnis dan kultur tanpa menimbulkan kesalahpahaman dan menimbulkan ketidaknyamanan dalam masyarakat global. Pada akhirnya, segala bentuk ektrimisme, radikalisme maupun fundamentalisme yang menggunkan caracara kekerasan atas nama agama yang bertentangan dengan prinsip Islam dan karakter masyarakat modern akan jauh dari lingkungan pesantren. Sebuah lembaga pendidikan Islam tertua di Indonesia, yang dari awal berdirinya memang syarat dengan nilai-nilai kemanusiaan dan menebarkan kedamaian di muka bumi.

\section{DAFTAR PUSTAKA}

Mas'ud, Abdurrahman. 2002. Dinamika Pesantren dan Madrasah. Yogyakarta: Pustaka Pelajar.

AF, Ahmad Gauf. 2007. "Islam Progresif: Wacana Pasca Arus Utama”, dalam Jurnal Taswirul Afkar, Edisi No. 22.

Rodger, Alex R. 1982. Educational and Faith in Open Society. Britain: The Handel Press.

Saleh, Badrus. 2002. "Pesantren dan Perdamaian Regional" dalam WWw.ditpertais.net/annualconference/ancon $06 / \mathrm{makalah} /$ Makalah\%20Badrus\% 20Sholeh.doc.

Tibi, Bassam. 2000. Ancaman Fundamentalisme: Rajutan Islam Politik dan Kekacauan Dunia Baru. Yogyakarta: Tiara Wacana.

Kurzman, Charles. 2001. Wacana Islam Liberal: Pemikiran Islam Kontemporer tentang Isu-isu Global. Jakarta: Paramadina.

Cunningham, F. 2002. Theories of Democracy: A Critical Introduction. New York: Routledge. 
Fazlurrahman. 1982. Islam And Modernity. Chicago:The University of Chicago Press.

Haedari, HM. Amin et al. 2004. Masa Depan Pesantren: Dalam Tantangan Modernitas dan Kompleksitas Global. Jakarta:IRD Press.

Piscatori, James P. 1988. Islam in a World of Nation-State. New York. etc.: Cambridge Univercity Press.

Esposito, John L. 1987. Islam and State. New York: Syracuse University Press.

Amstrong, Karen. 2005. "Islam : A short History" diterjemahkan oleh Fungky Kusnaedy Timur. Yogyakarta: Jendela.

Kuntowijoyo. 1997. Identitas Politik Umat Islam. Bandung: Mizan.

Rahmat, M. Imdadun. 2005. Arus Baru Islam Radikal. Jakarta: Erlangga.

Bruinessen, Martin van. 2004. ISIM, Netherlands Paper presented at the ISIM workshop on 'The Madrasa in Asia', 23-24 May. Dalam http:// murtaufiq.blogspot.com/2008 0901 archive.html.

Asmawy, Mohammad Said Al- 2002. Jihad Melawan Islam Ekstrem. Jakarta: Desentara.

Imarah, Muhammad. 1999. Fundamentalisme Dalam Perspektif Barat dan Islam, Terjemahan Abdul Hayyie al-Kattani. Jakarta: Gema Insani Press.

Abu, Murbu. 2004. "Memahami Terorisme di Indonesia", dalam A. Maftuh Abegebriel,(eds), NegaraTuhan:The Thematic Encyclopedia. Jakarta: SR-Ins Publishing.

Siradj, Said Aqiel. 1999. Islam Kebangsaan: Fiqih Demokartik Kaum Santri. Jakarta: Pustaka Ciganjur.

Zuhri, Saifudin. 1999. "Pendidikan Pesantren di Persimpangan Jalan"dalam Marzuki Wahid,dkk. Pesantren Masa Depan Wacana Pemberdayaan dan Transformasi Pesantren. Bandung: Pustaka Hidayah.

Arismunandar, Satrio. 1993. "Islam di Mata Media Massa Barat", dalam Jurnal Islamika, No 1 Juli-September, Jakarta: MISSI \& Bandung: Mizan.

Wahid, Abdurrahman. 2005. The Wall Street Journal, 30/12. 